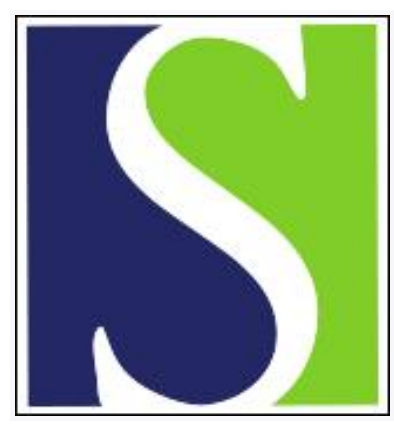

Scand J Work Environ Health 1997;23(5):342-350

https://doi.org/10.5271/sjweh.230

Issue date: Oct 1997

Mortality from nonmalignant respiratory diseases among male workers in Norwegian ferroalloy plants

by Hobbesland $\AA$, Kjuus $H$, Thelle DS

Key terms: amorphous silica; asthma; bronchitis; emphysema; ferrosilicon; lung disease; manganese; pneumonia

This article in PubMed: www.ncbi.nlm.nih.gov/pubmed/9403464

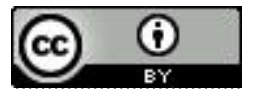




\title{
Mortality from nonmalignant respiratory diseases among male workers in Norwegian ferroalloy plants
}

\author{
by Ånund Hobbesland, MD,' Helge Kjuus, MD2, Dag S Thelle, MD³
}

\begin{abstract}
Hobbesland $\AA$, Kjuus $H$, Thelle DS. Mortality from nonmalignant respiratory diseases among male workers in Norwegian ferroalloy plants. Scand J Work Environ Health 1997;23(5):342-50.

Objectives This study examined mortality from nonmalignant respiratory diseases among ferroalloy workers. Methods The cohort comprised 14730 men employed for the first time in 1933-1990 and for at least 6 months in 1 of 12 plants. The duration of work in specific departments and exposure to amorphous silica in the ferrosilicon/silicon-metal (FeSi/Si-met) plants, estimated from a job-exposure matrix, were the main exposure variables. Deaths were observed during 1962-1990. The mortality was analyzed with the use of standardized mortality ratios (SMR) and internal comparisons of rates.

Results Overall mortality from nonmalignant respiratory diseases was not increased, but mortality from bronchitis, emphysema, and asthma combined was significantly increased among the men with at least 3 years of FeSi/Si-met furnace work (SMR 1.82, 16 deaths). A Poisson regression analysis of the mortality from these causes among 6359 employees in the FeSi/Si-met plants showed a significant increase of 0.06 per unit of amorphous silica exposure observed 10-20 years after the exposure. Six men died of pneumonia while still employed in a ferromanganese/silicomanganese (FeMn/SiMn) plant. No corresponding deaths occurred among employees in $\mathrm{FeSi} / \mathrm{Si}$-met plants. Only 2 deaths from pneumoconiosis were observed in the total cohort.

Conclusions Among employees in FeSi/Si-met plants increased mortality from bronchitis, emphysema, and asthma may be associated with previous exposure to amorphous silica. Deaths from pneumonia among FeMn/ SiMn workers may be associated with manganese exposure.
\end{abstract}

Key terms amorphous silica, asthma, bronchitis, emphysema, ferrosilicon, lung disease, manganese, pneumonia.

Workers in the ferroalloy industry have been exposed to a variety of gases, fumes, and dusts that may adversely affect the respiratory system. Among these, exposure to manganese compounds in plants producing ferromanganese (FeMn) and silicomanganese ( $\mathrm{SiMn}$ ) alloys has previously attracted special attention. As early as 1920 1940 a possible association between exposure to manganese compounds and an elevated morbidity and mortality from pneumonia was presented in several reports $(1-4)$

One of the reports presented an epidemic of lobar pneumonia in a small Norwegian community with a FeMn and SiMn producing plant (1). During 19241937 the mortality from lobar pneumonia showed an 8 -fold increase in this small community when compared with the national rate. The discharged smoke from the plant contained $30 \%$ manganese oxides in 1926 (1).
A high morbidity from pneumonia among workers exposed to manganese oxides in a plant manufacturing potassium permanganate was also observed in England (2). From this study in 1946 it was concluded that manganese was toxic to the respiratory epithelium and might affect any part of the respiratory tract from the nose to the alveoli (2). Later studies have shown that a primary respiratory inflammatory reaction (4) with symptoms of both acute $(5)$ and chronic $(6,7)$ bronchitis, together with an impaired resistance against respiratory tract infections $(4,7)$, may occur after exposure to manganese dioxide.

Workers in ferroalloy plants have also been exposed to fibrogenic dusts, mainly asbestos, and crystalline silica. The fibrogenic potential of asbestos and crystalline silica is well established $(8,9)$. There is however little evidence that silicosis can be caused by exposure to amorphous silica in these plants (10). But a few case

1 Telemark Central Hospital, Department of Occupational and Environmental Medicine, Skien, Norway.

2 National Institute of Occupational Health, Oslo, Norway.

3 Center for epidemiologic research, University of Oslo, Oslo, Norway.

Reprint requests to: Dr Ånund Hobbesland, Telemark Central Hospital, Department of Occupational and Environmental Medicine, N-3710 Skien, Norway. 
reports exist of ferroalloy workers with a pulmonary disease referred to as ferroalloy workers' disease (1115). In most of these reports an association with exposure to amorphous silica has been suspected. A possible association between amorphous silica exposure and an elevated prevalence of obstructive lung disease has previously been reported in a cross-sectional study among workers in a Norwegian plant producing ferrosilicon and ferrochromium (16).

We have recently presented the main causes of death from a study among 14730 male workers in 12 Norwegian ferroalloy plants, 8 plants producing ferrosilicon/ silicon-metal (FeSi/Si-met) and 4 producing FeMn/SiMn (17). The cohort included workers from the FeMn/SiMn plant where the aforementioned epidemic of lobar pneumonia had previously occurred in the surrounding community, and workers from the aforementioned plant producing ferrosilicon and ferrochromium. As far as we know, no previous study of mortality from nonmalignant lung diseases among workers in plants producing $\mathrm{FeSi} / \mathrm{Si}$-met or FeMn/SiMn has been published. The objective of the present study was to examine further the mortality from nonmalignant respiratory diseases within this cohort. The study was performed as a historical cohort study.

\section{Subjects and methods}

\section{The cohort}

The cohort consisted of 14730 men first employed during 1933-1990 and employed at least 6 months in 1 of 12 Norwegian ferroalloy plants. Each person was followed from the beginning of 1962 or, if hired later, from the date of first employment until death or emigration or the end date of the study, which was 31 December 1990. The total cohort was observed for 288886 person-years. Information on the individual causes of death and the death dates was obtained through linkage with Statistics Norway. The classification of causes of death followed the version of the International Classification of Diseases (ICDs) in use at the time the death occurred (ICD-7 ICD-9). Only the underlying cause of death was supplied and not the contributory causes. Due to the general uncertainty regarding death diagnoses, only 3 subgroups of nonmalignant respiratory diseases were studied: (i) pneu- monia, (ii) bronchitis, emphysema and asthma combined, and (iii) pneumoconiosis (table 1).

Four subcohorts were defined from the total cohort and analyzed separately. They were the 2 furnace worker groups in the FeSi/Si-met and FeMn/SiMn types of plants and the corresponding 2 groups of blue-collar nonfurnace workers in the same plants. These latter 2 groups were comprised of mechanics, electricians, transport workers, raw material workers, packers, and building and construction workers (18). The distributions of year of birth and duration of work within these 4 groups were similar (18). In addition also a fifth subcohort comprising 522 ferrochromium (FeCr) furnace workers from $2 \mathrm{FeSi}$ / Si-met plants was studied separately.

\section{Assessment of exposure}

In most of the analyses individual information about type of plant, work area (department), and duration of work was used as proxy for true exposure information. The dates for up to 10 employment periods in each plant were registered. In the analyses of mortality among workers in a particular department (eg, FeSi/Si-met furnace workers) the duration of work was calculated only with respect to work in the actual department (as was the start of the observation period). Therefore some workers were included both as furnace and nonfurnace workers with their respective duration of work.

Measurements of total dust exposure were studied for the furnace workers in 3 of the FeSi/Si-met plants. A total of 401 personal measurements, performed during 1974-1990, were available. The median and the 5th and 95th percentile values (in parentheses) of these measurements were $4.8 \mathrm{mg} / \mathrm{m}^{3}$ (1.5 \& 15.6) $\mathrm{mg} / \mathrm{m}^{3}$ for 1974 $1979,3.3(1.1 \& 13.8) \mathrm{mg} / \mathrm{m}^{3}$ for $1980-1985$, and 3.4 (1.1 \& 9.6) $\mathrm{mg} / \mathrm{m}^{3}$ for 1986 - 1990. However, information was lacking on the extent to which the measurements were representative for furnace workers during these periods or were confined to those most heavily exposed. Personal measurements of exposure to amorphous silica among furnace workers were only available from 1 of these plants, where 8 measurements of total silica ranged from $42 \%$ to $69 \%$ of the total dust level (median 54\%). In other measurements crystalline silica constituted $4-6 \%$ of the total dust. By subtraction we found that approximately $50 \%$ of the total dust exposure

Table 1. Codes from the 7th to the 9th versions of the International Classification of Diseases (ICD) used in classifying the causes of death from nonmalignant respiratory diseases with corresponding parts of the observation period.

\begin{tabular}{lccc}
\hline Cause of death & ICD-7 (1962-1968) & ICD-8 (1969-1985) & ICD-9 (1986-1990) \\
\hline All nonmalignant respiratory diseases & $241,470-527$ & $460-519$ & $460-519$ \\
Pneumonia & $480,490-493$ & $471,480-486$ & $480-487$ \\
Bronchitis, emphysema, asthma & $241,500-502$ & $490-493$ & $490-493,496$ \\
Pneumoconiosis & $523-524$ & $515-516$ & $500-506$ \\
\hline
\end{tabular}


of the furnace workers may be constituted of amorphous silica. Corresponding figures for workers in other departments were not available.

A job-exposure matrix for exposure to amorphous silica was constructed independently for 3 of the FeSi/Simet plants at the same time as the registration of the employment data. In each plant 2-4 experienced employees (including safety and health workers) were asked to discuss and score the average intensity of exposure to amorphous silica among employees in each department. Thus the job-exposure matrix for each plant became a joint assessment of these workers. Exposure to amorphous silica was scored by 0 (none), 0.2 (sporadic), 1 (low), 2 (medium), or 3 (high) for workers in each department. The same scores were used for all time periods due to the opinion of the collaborating workers. The matrices from the 3 plants were compared and appeared to be similar. They were then used to construct a final common matrix. Workers at the furnace smoke cleaning installation were scored by 3 , furnace workers and amorphous silica recovery workers by 2 , workers in crushing and packing, workers in building and construction, electricians and mechanics by 1 , and technical workers and transport workers by 0.2 . All others were scored by 0 (crude material workers, parts and accessories workers, laboratory workers, and office workers). This matrix was applied to all $8 \mathrm{FeSi} / \mathrm{Si}$-met plants. An amorphous silica index was calculated by multiplying the score with the duration of work. For each worker, cumulative exposure from work in various departments with different scores was calculated for each year from the start of employment. This exposure variable was used in an analysis of mortality from bronchitis, emphysema, and asthma. In this analysis 2096 workers were omitted due to unknown or specific work exposures that might have affected the respiratory system (eg, work at other types of furnaces). The analysis then included 6359 employees. A corresponding job-exposure matrix was not constructed for manganese exposure in the $4 \mathrm{FeMn} / \mathrm{SiMn}$ plants. For long periods of time 3 of these plants had previously also manufactured $\mathrm{FeSi}$ and other alloys in addition to manganese, and the lack of individual information about type of furnace work might imply low validity for a job-exposure matrix. Within the $\mathrm{FeSi} / \mathrm{Si}$ met plants other metals had been produced in separate departments, and such work was noted in the actual employment records.

\section{Data analysis}

Standardized mortality ratios (SMR) with $95 \%$ confidence intervals $(95 \% \mathrm{CI}$ ) were calculated for the various causes of death by use of national, male, 5-year agespecific mortality rates for each year from 1962 through 1990. The Epicure program package was used for both the SMR analyses and the internal comparisons of rates with a Poisson regression analysis (19). In the regression analyses the P-value for trend was calculated as the $\mathrm{P}$-value for the likelihood ratio test when the variable (amorphous silica index) was withdrawn from the final model after the categories of the variable had been scored by their mean values. The data were analyzed for mortality in time-related categories of employment status (active and inactive person-time) $(20,21)$. Active persontime was defined as all person-time from the start of follow-up until the end of the last employment period added by 0.1 year (17). Inactive person-time was defined as person-time passing after this point. Induction time analyses (ie, exposure window analyses) were also performed (21). In them only exposure or work during a period defined by its length (the width of the window) and the distance in time before observation was considered to be etiologically relevant and categorized as exposure or work. Short-term work was divided from longterm work at the cutoff point of 3 years.

\section{Influence of smoking habits}

Only an indirect evaluation of the influence of individual smoking on mortality could be performed, as only $18.5 \%$ of the deceased (from all causes) could be categorized into ever or never smokers (17). However, recent smoking status information was available for 1989-1990 for over $90 \%$ of the men employed in some of the plants. The prevalence of smoking in these plants was calculated for 5-year birth cohorts of the furnace and nonfurnace workers and for the corresponding Norwegian male population at the time (22). By assuming that these data were representative also for previous workers, we could evaluate the extent to which our results may have been biased by smoking. The Axelson model for confounding (23) was used with the formulation for relative risk presented by Checkoway and his co-workers (24). The relative risk due to confounding (RRc) was expressed as

$$
R R c=\left[\left(P_{s}-\exp \right)\left(R_{s}-1\right)+1\right] /[(\text { Ps-ref })(R R s-1)+1],
$$

where Ps-exp and Ps-ref were the proportions of smokers in the exposed and reference group, respectively, and the $\mathrm{RR}_{\mathrm{s}}$ was the independent relative risk due to smoking. According to results from a previous Norwegian study a $\mathrm{RR}_{\mathrm{s}}$ of 8 was used for deaths from bronchitis, emphysema and asthma combined (25). Further details about the cohort and the applied methods of analyses have been presented elsewhere $(17,18)$.

\section{Results}

The mortality from all nonmalignant respiratory diseases was neither elevated for the employees in the FeSi/Si- 
met plants (SMR 1.01, 116 deaths) nor for those in the FeMn/SiMn plants (SMR 1.01, 84 deaths) (table 2). Neither was the mortality from any of the 3 main subgroups of nonmalignant respiratory diseases significantly elevated. There was only 1 death from pneumoconiosis in each of the 2 plant categories.

Table 3 shows further analyses within the 5 subcohorts of workers stratified by duration of work. Within the FeSi/Si-met plants a significantly increased mortality from bronchitis, emphysema and asthma (combined) was found for the long-term furnace workers (SMR 1.82,
16 deaths). Excess deaths from bronchitis, emphysema and asthma combined was also found for the short-term FeMn/SiMn furnace workers (SMR 2.36, 11 deaths). Ten of these deaths occurred 10 years or more after the termination of furnace work. The mortality from pneumonia was not significantly increased in any of the subgroups. Neither did further analyses reveal any associations between mortality from pneumonia and duration of work (with or without various lags and various exposure windows) in the 2 groups of workers in the FeMn/SiMn plants. Among the ferrochromium furnace workers only

Table 2. Observed and expected numbers of deaths from nonmalignant respiratory diseases. (SMR $=$ standardized mortality ratio, $95 \%$ $\mathrm{Cl}=95 \%$ confidence interval, FeSi/Si-met = ferrosilicon/silicon-metal, FeMn/SiMn = ferromanganese/silicomanganese)

\begin{tabular}{|c|c|c|c|c|}
\hline Cause of death & Observed & Expected & SMR & $95 \% \mathrm{Cl}$ \\
\hline \multicolumn{5}{|l|}{ Pneumonia } \\
\hline $\begin{array}{l}\text { Employees in FeSi/Si-met plantsa } \\
\text { Employees in FeMn/SiVn plants }\end{array}$ & $\begin{array}{l}53 \\
44\end{array}$ & $\begin{array}{l}59.97 \\
42.72\end{array}$ & $\begin{array}{l}0.88 \\
1.03\end{array}$ & $\begin{array}{l}0.66-1.16 \\
0.75-1.38\end{array}$ \\
\hline \multicolumn{5}{|l|}{ Bronchitis, emphysema, asthma } \\
\hline $\begin{array}{l}\text { Employees in FeSi/Si-met plants }{ }^{a} \\
\text { Employees in FeMn/SiMn plants }\end{array}$ & $\begin{array}{l}56 \\
32\end{array}$ & $\begin{array}{l}45.25 \\
33.17\end{array}$ & $\begin{array}{l}1.24 \\
0.96\end{array}$ & $\begin{array}{l}0.93-1.61 \\
0.66-1.36\end{array}$ \\
\hline \multicolumn{5}{|l|}{ Pneumoconiosis } \\
\hline $\begin{array}{l}\text { Employees in FeSi/Si-met plantsa } \\
\text { Employees in FeMn/SiMn plants }\end{array}$ & $\begin{array}{l}1 \\
1\end{array}$ & $\begin{array}{l}0.83 \\
0.61\end{array}$ & $\begin{array}{l}1.21 \\
1.65\end{array}$ & $\begin{array}{l}0.03-6.72 \\
0.04-9.20\end{array}$ \\
\hline \multicolumn{5}{|l|}{ All nonmalignant respiratory diseases } \\
\hline $\begin{array}{l}\text { Employees in FeSi/Si-met plantsa } \\
\text { Employees in FeMn/SiMn plants }\end{array}$ & $\begin{array}{r}116 \\
84\end{array}$ & $\begin{array}{r}115.16 \\
83.13\end{array}$ & $\begin{array}{l}1.01 \\
1.01\end{array}$ & $\begin{array}{l}0.84-1.21 \\
0.81-1.25\end{array}$ \\
\hline
\end{tabular}

${ }^{2} \mathrm{~N}=8455$.

b $N=6275$.

Table 3. Observed and expected numbers of deaths from nonmalignant respiratory diseases in five groups of workers, categorized by duration of work. (SMR = standardized mortality ratio, 95\% Cl =95\% confidence interval, FeSi/Si-met = ferrosilicon/silicon-metal, FeMn/ $\mathrm{SiMn}=$ ferromanganese/silicomanganese)

\begin{tabular}{|c|c|c|c|c|c|c|c|c|}
\hline \multirow[t]{3}{*}{ Cause of death } & \multicolumn{8}{|c|}{ Duration of work in department } \\
\hline & \multicolumn{4}{|c|}{$<3$ years } & \multicolumn{4}{|c|}{$\geq 3$ years } \\
\hline & $\begin{array}{c}\text { ob- } \\
\text { served }\end{array}$ & $\begin{array}{c}\text { Ex- } \\
\text { pected }\end{array}$ & SMR & $95 \% \mathrm{Cl}$ & $\begin{array}{c}\text { Ob- } \\
\text { served }\end{array}$ & $\begin{array}{c}\text { Ex- } \\
\text { pected }\end{array}$ & SMR & $95 \% \mathrm{Cl}$ \\
\hline \multicolumn{9}{|l|}{ Pneumonia } \\
\hline $\begin{array}{l}\text { FeSi/Si-met furnace workers }(N=2517) \\
\text { Nonfurnace workers in FeSi/Si-met plants }(N=3695) \\
\text { FeMn/SiMn furnace workers }(N=3086) \\
\text { Nonfurnace workersa in FeMn/SiMn plants }(N=3119) \\
\text { Ferrochromium furnace workers }(N=522)\end{array}$ & $\begin{array}{l}4 \\
4 \\
9 \\
5 \\
1\end{array}$ & $\begin{array}{l}4.01 \\
7.11 \\
5.16 \\
5.16 \\
1.17\end{array}$ & $\begin{array}{l}1.00 \\
0.56 \\
1.74 \\
0.97 \\
0.85\end{array}$ & $\begin{array}{l}0.27-2.55 \\
0.15-1.44 \\
0.80-3.31 \\
0.31-2.26 \\
0.02-4.75\end{array}$ & $\begin{array}{r}10 \\
16 \\
12 \\
19 \\
6\end{array}$ & $\begin{array}{r}11.22 \\
22.92 \\
13.58 \\
13.91 \\
4.93\end{array}$ & $\begin{array}{l}0.89 \\
0.70 \\
0.88 \\
1.37 \\
1.22\end{array}$ & $\begin{array}{l}0.43-1.64 \\
0.40-1.13 \\
0.46-1.54 \\
0.82-2.13 \\
0.45-2.65\end{array}$ \\
\hline \multicolumn{9}{|l|}{ Bronchitis, emphysema, asthma } \\
\hline $\begin{array}{l}\text { FeSi/Si-met furnace workers }(\mathrm{N}=2517) \\
\text { Nonfurnace workers }{ }^{\mathrm{a}} \text { in FeSi/Si-met plants }(\mathrm{N}=3695) \\
\text { FeMn/SiMn furnace workers }(\mathrm{N}=3086) \\
\text { Nonfurnace workersa in FeMn/SiMn plants }(\mathrm{N}=3119) \\
\text { Ferrochromium furnace workers }(\mathrm{N}=522)\end{array}$ & $\begin{array}{r}1 \\
6 \\
11 \\
3 \\
1\end{array}$ & $\begin{array}{l}3.83 \\
5.18 \\
4.66 \\
4.37 \\
1.21\end{array}$ & $\begin{array}{l}0.26 \\
1.16 \\
2.36 \\
0.69 \\
0.83\end{array}$ & $\begin{array}{l}0.01-1.45 \\
0.42-2.52 \\
1.18-4.22 \\
0.14-2.01 \\
0.02-4.60\end{array}$ & $\begin{array}{r}16 \\
15 \\
8 \\
7 \\
5\end{array}$ & $\begin{array}{r}8.80 \\
16.67 \\
10.92 \\
10.69 \\
3.78\end{array}$ & $\begin{array}{l}1.82 \\
0.90 \\
0.73 \\
0.65 \\
1.32\end{array}$ & $\begin{array}{l}1.04-2.95 \\
0.50-1.48 \\
0.32-1.44 \\
0.26-1.35 \\
0.43-3.09\end{array}$ \\
\hline \multicolumn{9}{|l|}{ All nonmalignant respiratory diseases } \\
\hline $\begin{array}{l}\text { FeSi/Si-met furnace workers }(N=2517) \\
\text { Nonfurnace workers in FeSi/Si-met plants }(N=3695) \\
\text { FeMn/SiMn furnace workers }(N=3086) \\
\text { Nonfurnace workers in FeMn/SiMn plants }(N=3119) \\
\text { Ferrochromium furnace workers }(N=522)\end{array}$ & $\begin{array}{r}6 \\
11 \\
22 \\
8 \\
2\end{array}$ & $\begin{array}{r}8.67 \\
13.52 \\
10.83 \\
10.49 \\
2.62\end{array}$ & $\begin{array}{l}0.69 \\
0.81 \\
2.03 \\
0.76 \\
0.76\end{array}$ & $\begin{array}{l}0.25-1.51 \\
0.41-1.46 \\
1.27-3.07 \\
0.33-1.50 \\
0.09-2.76\end{array}$ & $\begin{array}{l}30 \\
33 \\
21 \\
33 \\
12\end{array}$ & $\begin{array}{r}21.86 \\
43.19 \\
26.81 \\
26.93 \\
9.49\end{array}$ & $\begin{array}{l}1.37 \\
0.76 \\
0.78 \\
1.23 \\
1.26\end{array}$ & $\begin{array}{l}0.93-1.96 \\
0.53-1.07 \\
0.48-1.20 \\
0.84-1.72 \\
0.65-2.21\end{array}$ \\
\hline
\end{tabular}

a Comprised of 6 main groups of blue-collar workers (mechanics, electricians, transport workers, raw material workers, packers, and building and construction workers). 
14 deaths from all nonmalignant respiratory diseases were observed, and none of the SMR values were significantly increased.

As deaths from pneumonia might be associated with recent occupational exposures, the mortality from pneumonia was studied for active and inactive person-time (not shown). None of the SMR values were significantly elevated, but 3 deaths occurred during active persontime among the FeMn/SiMn furnace workers (SMR 2.18, 95\% CI 0.45-6.36) and 3 deaths occurred among the nonfurnace workers in the same plants (SMR 1.64, 95\% CI 0.38-5.33). The 6 deaths occurred during 19721984. None of these deaths occurred during the first 3 workyears. In the remaining cohort no death from pneumonia occurred during active person-time.

The elevated mortality from bronchitis, emphysema and asthma combined among the FeSi/Si-met furnace workers was further analyzed by duration of work. For the categories $3-9,10-19$ and $\geq 20$ years, the SMR values were 2.49 (10 deaths), 1.22 ( 3 deaths) and 1.29 ( 3 deaths), respectively (not shown). Because of these results we also performed exposure window analyses (table 4). For work performed 5-15, 10-20, and 1525 years before each year of observation the SMR values were highest among those who had worked 5 years or more during the exposure window. The highest SMR for this category was found with the exposure window $10-$ 20 years (SMR 1.90, 7 deaths). The mortality by duration of $\mathrm{FeSi} / \mathrm{Si}$-met furnace work $(0,<5$, and $\geq 5$ years $)$ within this 10 - to 20-year exposure window was further examined with a Poisson regression analysis with adjustment for age, calendar time, length of follow-up, and the plants' location (rural, urban) (not shown). The regression analysis showed increasing RR values with increasing duration of work (RR 1.00, 1.38, and 2.29, respectively), but none of the values were significantly elevated. Trend analyses showed a nonsignificant proportional increase of 0.101 in risk per year of work in this exposure window $(\mathrm{P}=0.14)$.

Table 5 shows the RR values for deaths from bronchitis, emphysema and asthma combined in categories of the amorphous silica index estimated from the job-expo- sure matrix . The exposure window $10-20$ years was applied also in this analysis. A total of 38 deaths from these causes was observed during 120134 person-years in this group of 6359 employees. A significantly elevated RR of 3.43 was found for the highest exposure category. The trend analysis revealed a significantly increasing risk of 0.06 per exposure unit within this exposure window $(\mathrm{P}=0.01)$. SMR analyses for the same categories of cumulative exposure to amorphous silica ( 0 $4,5-14$, and $\geq 15$ years) within the same exposure window showed SMR values of 0.96 (22 deaths, 96862 person-years), 1.09 (8 deaths, 17909 person-years), and 2.86 ( 8 deaths, 5363 person-years), respectively. The SMR of the highest exposure category was significantly elevated (95\% CI 1.24-5.64).

Finally we also performed a Poisson regression analysis of the mortality rates for bronchitis, emphysema and asthma combined in which the rates were compared between the 4 main groups of workers (furnace and nonfurnace workers in the FeSi/Si-met and FeMn/SiMn types of plants). The variables included were attained age $(<50,50-59,60-69,70-79, \geq 80$ years $)$, calendar time (1962-1975, 1976-1990), length of followup $(<15, \geq 15$ years), location of plant (rural, urban), worker group 2 furnace worker groups ( $\mathrm{FeSi} / \mathrm{Si}$-met and FeMn/SiMn) and 2 nonfurnace reference groups], and duration of work $(<3, \geq 3$ years). In this analysis, each worker had to be defined as belonging to only 1 group of workers, and the duration of work was calculated as the duration within this group. Those who had been both furnace and nonfurnace workers were defined as furnace workers. This procedure reduced the number of nonfurnace FeSi/Si-met workers from 3695 (table 3) to 3354 and the number of nonfurnace FeMn/SiMn workers from 3119 to 2390 . The number of furnace workers was unchanged from previous analyses (table 3 ). With this model the RR was 2.04 (95\% CI $0.98-4.25$ ) for longterm $\mathrm{FeSi} / \mathrm{Si}$-met furnace work, in comparison with longterm nonfurnace work in the same plants, and $2.90(95 \%$ CI 1.23-6.82) for long-term FeSi/Si-met furnace work, in comparison with long-term FeMn/SiMn furnace work (not shown).

Table 4. Observed numbers of deaths for bronchitis, emphysema, and asthma analyzed with various exposure windows for 2517 ferrosilicon/silicon-metal furnace workers. (SMR $=$ standardized mortality ratio, $95 \% \mathrm{Cl}=95 \%$ confidence interval)

\begin{tabular}{|c|c|c|c|c|c|c|c|c|c|}
\hline \multirow[t]{3}{*}{ Exposure window } & \multicolumn{9}{|c|}{ Duration of work in exposure window } \\
\hline & \multicolumn{3}{|c|}{0 years } & \multicolumn{3}{|c|}{$0.1-4.9$ years } & \multicolumn{3}{|c|}{$\geq 5$ years } \\
\hline & $\begin{array}{c}\text { Ob- } \\
\text { served }\end{array}$ & SMR & $95 \% \mathrm{Cl}$ & $\begin{array}{c}\text { Ob- } \\
\text { served }\end{array}$ & SMR & $95 \% \mathrm{Cl}$ & $\begin{array}{c}\text { Ob- } \\
\text { served }\end{array}$ & SMR & $95 \% \mathrm{Cl}$ \\
\hline $0-10$ years & 9 & 1.10 & $0.50-2.08$ & 5 & 2.35 & $0.76-5.48$ & 3 & 1.31 & $0.27-3.84$ \\
\hline $5-15$ years & 7 & 1.00 & $0.40-2.05$ & 4 & 1.68 & $0.46-4.29$ & 6 & 1.86 & $0.68-4.06$ \\
\hline $10-20$ years & 6 & 0.95 & $0.35-2.06$ & 4 & 1.52 & $0.41-3.90$ & 7 & 1.90 & $0.77-3.92$ \\
\hline $15-25$ years & 7 & 1.15 & $0.46-2.37$ & 4 & 1.32 & $0.36-3.39$ & 6 & 1.71 & $0.63-3.72$ \\
\hline $20-30$ years & 10 & 1.54 & $0.74-2.83$ & 3 & 0.96 & $0.20-2.80$ & 4 & 1.33 & $0.36-3.41$ \\
\hline
\end{tabular}


Table 5. Poisson regression modeling of mortality from bronchitis, emphysema, and asthma including cumulative exposure to amorphous silica among 6359 employees in eight ferrosilicon/silicon-metal plants. ( $R R=$ rate ratio, $95 \% \mathrm{Cl}=95 \%$ confidence interval)

\begin{tabular}{|c|c|c|c|c|c|}
\hline Variable & $\mathrm{RR}^{\mathrm{a}}$ & $95 \% \mathrm{Cl}$ & $\begin{array}{l}\text { P-value } \\
(\text { LRT })^{b}\end{array}$ & Slopec & $\begin{array}{l}\text { P-value } \\
\text { (trend) }\end{array}$ \\
\hline \multicolumn{6}{|l|}{ Age } \\
\hline $\begin{array}{l}<50 \text { years } \\
50-59 \text { years } \\
60-69 \text { years } \\
70-79 \text { years } \\
\geq 80 \text { years }\end{array}$ & $\begin{array}{r}1.00 \\
7.59 \\
15.36 \\
36.37 \\
66.06\end{array}$ & $\begin{array}{c}1.95-29.5 \\
4.11-57.4 \\
9.51-139.0 \\
12.39-352.3\end{array}$ & $\begin{array}{c}. . \\
\ddot{.} \\
\ddot{0} \\
0.000\end{array}$ & $\begin{array}{l}. . \\
" . \\
. . \\
. . \\
. .\end{array}$ & $\begin{array}{l}. . \\
. " \\
. . \\
. . \\
. .\end{array}$ \\
\hline \multicolumn{6}{|c|}{ Time (calendar years) } \\
\hline $\begin{array}{l}1962-1975 \\
1976-1990\end{array}$ & $\begin{array}{l}1.00 \\
1.72\end{array}$ & $0.61-4.81$ & 0.32 & $\ddot{~} \ddot{.}$ & $\begin{array}{l}. . \\
. .\end{array}$ \\
\hline \multicolumn{6}{|c|}{ Length of follow-up } \\
\hline $\begin{array}{l}<15 \text { years } \\
\geq 15 \text { years }\end{array}$ & $\begin{array}{l}1.00 \\
0.67\end{array}$ & $0.25-1.75$ & $\ddot{0.43}$ &. &.. \\
\hline \multicolumn{6}{|c|}{$\begin{array}{l}\text { Amorphous silica index in exposure- } \\
\text { window } 10-20 \text { years }{ }^{\mathrm{a}}\end{array}$} \\
\hline $\begin{array}{l}0-4 \\
5-14 \\
\geq 15\end{array}$ & $\begin{array}{l}1.00 \\
1.30 \\
3.43\end{array}$ & $\begin{array}{l}0.57-2.94 \\
1.48-7.95\end{array}$ & $\begin{array}{c}. . \\
0.03\end{array}$ & 0.06 & $\begin{array}{c}\ddot{0} \\
0.01\end{array}$ \\
\hline \multicolumn{6}{|l|}{ Plant location } \\
\hline $\begin{array}{l}\text { Rural } \\
\text { Urban }\end{array}$ & $\begin{array}{l}1.00 \\
1.54\end{array}$ & $0.81-2.92$ & $0 . \ddot{18}$ &.. & $\ddot{.}$ \\
\hline
\end{tabular}

\section{Discussion}

The main findings from this study are the increased mortality from bronchitis, emphysema and asthma combined for long-term FeSi/Si-met furnace work and for the highest category of the amorphous silica index. The significantly increased RR of 2.90 for these causes of death for long-term FeSi/Si-met furnace work compared with long-term FeMn/SiMn furnace work is compatible with an effect of exposure factor(s) which mainly occur(s) at FeSi/Si-met furnaces. The excess deaths from pneumonia among the FeMn/SiMn furnace workers during active person-time and the low number of deaths from pneumoconiosis in the total cohort should also be noted. Previously, 2 mortality studies among ferroalloy workers in ferrochromium manufacturing have been published. Neither of them revealed excess deaths from nonmalignant respiratory diseases $(26,27)$.

\section{Deaths from bronchitis, emphysema and asthma combined}

Previous results from cross-sectional studies of pulmonary function and symptoms among workers exposed to amorphous silica dust are divergent. A possible association between exposure and symptoms or signs of obstructive lung disease has been reported for Norwegian FeSi and FeCr furnace workers (16) and for workers exposed to amorphous silica in a French chemical plant
(28). On the other hand, nonpositive studies have been reported from another Norwegian FeSi plant, where no association between long-term employment and ventilatory impairment was found (29), and from 2 industrial facilities in the United States, where no association between amorphous silica exposure and pulmonary function was observed (30). These cross-sectional studies may have lost workers who withdrew early from dusty jobs due to developing pulmonary disease. Regarding other types of studies, the case reports of pulmonary disease among workers exposed to amorphous silica in ferroalloy plants are in accordance with our findings (11-15). A study of the inhalation toxicity of amorphous silicas and quartz dust in rats also showed that all test materials induced inflammation, alveolar bronchiolization, and fibrosis (31). The amorphous silicas were cleared quickly, but the changes in the lungs were only partly reversed after exposure to some of the amorphous silicas.

A potential reversible pulmonary disease may exist with a causal relation to exposure to amorphous silica. Though this disease has been referred to as a sort of pneumoconiosis which starts as chemical pneumonitis and may regress if the exposure ceases (14), it seems reasonable that possible deaths from this disease may have been diagnosed as bronchitis, asthma or emphysema and not as silicosis. The reversibility of this condition may also correspond to our findings of an associa- 
tion between duration of work and mortality in the exposure window analyses but no association with duration of work (in 4 categories) in the ordinary analyses.

There is no previous indication of increased mortality from nonmalignant respiratory diseases $10-20$ years after exposure (table 5). The selection of this exposure window variable should be based on a priori biological knowledge or on likelihood-based goodness-of-fit statistics and not on the highest estimate criterion (32). We therefore evaluated all the variables used in table 4 in Poisson regression analyses similar to that presented in table 5. The exposure window variable $10-20$ years used in table 5 was the only of the exposure-window variables which showed a $\mathrm{P}$-value of $<0.05$ in the likelihood ratio test when the variable was withdrawn from the model. This variable also showed the highest estimate of the RR values. Thus this observed time-relation may reflect a biological time-relation between exposure to amorphous silica and an increased risk of dying from bronchitis, emphysema, or asthma 10-20 years later.

According to available exposure information, amorphous silica seems to be the quantitatively dominating type of dust in furnace smoke, and, with respect to results from both human $(11-16,28)$ and animal (31) studies, amorphous silica exposure may be associated with the increased mortality from bronchitis, emphysema and asthma observed for the FeSi/Si-met furnace workers. However, this exposure factor may be correlated with other unknown exposure factors in furnace smoke. In addition, relevant exposures from other sources may also occur, such as phosphine gas, which is an important systemic poison that may cause pulmonary irritation and also pulmonary edema in acute intoxication $(33,34)$. Phosphine gas has been detected in at least 2 of the plants, and in 1 of these more than $50 \%$ of the furnace workers employed in 1988 had ever experienced work-related symptoms (headache, vertigo, nausea) possibly caused by phosphine exposure. The frequency and level of this possible phosphine exposure is however unknown.

The increased mortality from bronchitis, emphysema and asthma among the short-term FeMn/SiMn furnace workers during the period 10 years or more after furnace work was terminated was probably not associated with exposures in furnace work as similar results regarding mortality during inactive person-time was not revealed for the long-term workers at the same furnaces.

\section{Deaths from pneumonia}

The 6 deaths from pneumonia during active person-time (48 958 person-years) among the employees in the FeMn/ SiMn plants is of interest, as no corresponding deaths occurred during active person-time (66 057 person-years) in the FeSi/Si-met plants. For the active person-time an SMR of lower than 1.00 is expected for all causes of death (20). We suppose that this is true also for mortality from pneumonia and that a more appropriate comparison group (of currently employed men) would have given a lower expected value. Four of the 6 deaths occurred among employees in the plant where the aforementioned epidemic of lobar pneumonia had previously occurred in the surrounding community (1). However, that finding was probably not due to the overreporting of pneumonia in this community as the SMR for pneumonia among employees in the plant was only 1.02 for the inactive person-time. This plant was also the largest, and active person-time constituted $47 \%$ of all active person-time in the $4 \mathrm{FeMn} / \mathrm{SiMn}$ plants. Available data from the personal monitoring of total manganese exposure among the furnace workers in this plant during 1979-1991 showed a median of $0.99 \mathrm{mg} / \mathrm{m}^{3}$. The values had been lower in recent years, and in 1990 a median value of $0.51 \mathrm{mg} / \mathrm{m}^{3}$ was found for total manganese exposure (18). The average manganese exposure level during 1979-1991 was close to that reported in a Belgian study in which a higher prevalence of both respiratory symptoms and recent episodes of acute bronchitis was found in the manganese-exposed group (5). The same result was not found in a later Belgian study in which the geometric means for manganese exposure were 0.22 and $0.95 \mathrm{mg} / \mathrm{m}^{3}$ for respirable and total dust, respectively (35). In the present study no death from pneumonia occurred for the active person-time category during 19851990. During this period the exposure to manganese among the furnace workers was probably lower than before 1985. However, no association between manganese exposure as such and pneumonia was observed in this study, and other explanations may exist (eg, correlated work exposures).

\section{Deaths from pneumoconiosis}

Two men in the total cohort died from pneumoconiosis (SMR 1.39, 95\% CI 0.17-5.02). They were 49 and 58 years of age when they were first employed in this industry and may thus have been exposed to fibrogenic agents elsewhere. Though pneumoconiosis may have been underreported as the underlying cause of death, our results indicate that men exposed in these plants have not increased their risk of irreversible pneumoconiosis. Such a finding has been debated earlier as an old clinical study from 1 of the participating plants reported 30 sure and 29 doubtful cases of silicosis among 208 workers (36). Our results are however in accordance with those of several other studies (10).

\section{Strengths and limitations of the study}

The main strengths of our study are the large size of the cohort (14 730 employees), the long-term follow-up (median 20.7 years) (17), the low proportion lost to follow- 
up (3\%) (17), the almost complete information about the cause of death (17), and the ability to study mortality in relation to work in separate departments.

The main limitations, on the other hand, are the general uncertainty which concerns the death diagnoses, the probably low distinction between asthma, bronchitis and emphysema which necessitated pooled analyses, the insufficient industrial hygiene data, and the incomplete data on confounding variables, in particular for smoking.

The job-exposure matrix for amorphous silica was based on subjective judgments, which also included the opinion that no major changes in the general exposure level had occurred over time. Analyses of available personal measurements of total dust exposure among the furnace workers indicated a decrease in the exposure level over time both in the FeSi/Si-met and in the FeMn/ SiMn plants. This and other possible errors in characterizing exposure may have attenuated the exposure-response relation in the analyses based on the job-exposure matrix.

Cigarette smoking was probably the most important confounding factor in this study. As individual smoking data were limited, we evaluated smoking habits among the currently employed men in $4 \mathrm{FeSi} / \mathrm{Si}$-met plants in 1989 - 1990. Among the furnace workers born in 19401974 the median 5-year birth cohort proportion of smokers was 0.58 . The corresponding value for the nonfurnace workers was 0.44 , and that of the general population was 0.40 (22). Among the men born before 1940 only small differences were observed between the groups (proportions $0.43,0.41$ and 0.37 for furnace, nonfurnace and the general population, respectively). Furthermore, we performed an indirect evaluation of the potential influence of these differences in smoking habits on the observed RR values. Using the presented formula (24) and the proportions of smokers in 1989-1990 among the men born in 1940 or later, we found that differences in smoking habits could only explain an RR of 1.24 for furnace workers, compared with the nonfurnace workers, and an RR of 1.34 for furnace workers versus the general male population. Thus neither the SMR of 1.82 for long-term $\mathrm{FeSi} / \mathrm{Si}$-met furnace workers nor the observed RR of 2.04 for long-term furnace work compared with long-term nonfurnace work in the FeSi/Si-met plants can be explained only by differences in smoking habits. A new regression analysis corresponding to that presented in table 5 was performed with a smoking status variable included where the RR for furnace versus other workers was forced to be 1.24 . This procedure reduced the RR of the highest category of the amorphous silica index from 3.43 (95\% CI 1.48 - 7.95) to 2.98 (95\% CI 1.29-6.91). All the other RR values were close to those presented in table 5 . Thus the lack of real information about smoking habits in this analysis has probably not led to any serious bias. At least the differences in smok- ing habits may also partly have been adjusted for by the inclusion of the rural-urban location variable in the regression analysis.

\section{Concluding remarks}

The increased mortality from bronchitis, emphysema and asthma among workers in the FeSi/Si-met plants may be associated with previous amorphous silica exposure. However, due to insufficient industrial hygiene data and possible exposure to other factors around the furnaces, no firm conclusions can be drawn with regard to this relationship. In spite of limited data on smoking it is unlikely that the observed differences in mortality are due to differences in smoking habits. The 6 deaths from pneumonia among employees in the FeMn/SiMn plants during active person-time may be associated with manganese or correlated exposure. Finally, the results did not indicate any increased risk of irreversible pneumoconiosis.

\section{Acknowledgments}

This project has been supported by grants from the Work Environment Fund of the Confederation of Norwegian Business and Industry (NHO). We are also grateful to Ole Tormod Fure at the Safety, Health and Environmental Secretariat for the Norwegian Smelters for his assistance in the cooperation with participating plants and the financial support.

\section{References}

1. Elstad D. Manganholdig fabrikkrøk som medvirhende årsak ved pneumonimepidemier $\mathrm{i}$ en industribygd [Factory-smoke containing manganese as predisposing cause in epidemics of pneumonia in an industrial district]. Nor Mag Lœgevidensk $1939 ; 3: 2527-33$.

2. Lloyd Davies TA. Manganese pneumonitis. $\mathrm{Br} \mathrm{J}$ Ind Med 1946;3:111-35.

3. Lloyd Davies TA, Harding HE. Manganese pneumonitis: further clinical and experimental observations. Br J Ind Med 1949;6:82-. 90 .

4. Bergström R. Acute pulmonary toxicity of manganese dioxide. Scand J Work Environ Health 1977;3 suppl 1:1-41.

5. Roels H, Lauwerys R, Buchet JP, Genet P, Sarhan MJ, Hanotiau I, et al. Epidemiological survey among workers exposed to manganese: effects on lung, central nervous system, and some biological indices. Am J Ind Med 1987;11:307-27.

6. Oberdoerster G, Cherian G. Manganese. In: Clarkson TW, Friberg 1, Nordberg GF, Sager PR, editors. Biological monitoring of toxic metals. New York (NY): Plenum Press 1988: $283-301$.

7. Saric M. Occupational and environmental exposures and nonspecific lung disease - a review of selected studies. Isr J Med Sci 1992;28:509-12. 
8. Mossmann BT, Gee JBL. Asbestos-related diseases. N Engl J Med 1989;320:1721-30.

9. Balaan MR, Banks DE. Silicosis. In: Rom WN, editor. Environmental and occupational medicine. Boston/Toronto/London: Little, Brown and Company, 1992:345 - 58.

10. Swensson A, Kvarnström K, Bruce T, Edling NPG, Glömme J. Pneumoconiosis in ferrosilicon workers - a follow-up study. J Occup Med 1971;13:427-32.

11. Princi F, Miller LH, Davis A, Cholak J. Pulmonary disease of ferroalloy workers. J Occup Med 1962;4:301-10.

12. Davies JCA. Inhalation hazards in the manufacture of silicon alloys. Cent Afr J Med 1974;20:140-3

13. Taylor DM, Davies JCA. Ferro-alloy workers' disease - a report of a recent case against the background of twelve years' experience. Cent Afr J Med 1977;23:28-32

14. Bowie DSJ. Ferro alloy worker's disease. Cent Afr J Med 1978;24:81-6

15. Vitums VC, Edwards MJ, Niles NR, Borman JO, Lowry RD. Pulmonary fibrosis from amorphous silica dust, a product of silica vapor. Arch Environ Health 1977;32:62 - 8.

16. Langård S. A survey of respiratory symptoms and lung function in ferrochromium and ferrosilicon workers. Int Arch Occup Environ Health 1980;46:1—9.

17. Hobbesland $\AA$, Kjuus H, Thelle D. A study of mortality among 14730 male workers in 12 Norwegian ferroalloy plants: cohort characteristics and the main causes of death. Occup Environ Med 1996;53:540 6 .

18. Hobbesland $\AA$, Kjuus H, Thelle D. Mortality from cardiovascular diseases and sudden death in ferroalloy plants. Scand J Work Environ Health 1997;23:334-41.

19. Preston DL, Lubin JH, Pierce DA, McConney ME. Epicure. Seattle (WA): Hirosoft International Corporation, 1993.

20. Steenland K, Stayner L. The importance of employment status in occupational cohort mortality studies. Epidemiology 1991; 2:418-23.

21. Pearce N. Methodological problems of time-related variables in occupational cohort studies. Rev Epidémiol Santé Publique 1992;40:43-54

22. Rønneberg A, Lund KE, Hafstad A. Lifetime smoking habits among Norwegian men and women born between 1890 and 1974. Int J Epidemiol 1994;23:267-76.

23. Axelson $O$. Aspects on confounding in occupational health epidemiology [letter]. Scand J Work Environ Health 1978;4:
98-102.

24. Checkoway H, Heyer NJ, Demers PA, Breslow NE. Mortality among workers in the diatomaceous earth industry. $\mathrm{Br} \mathrm{J}$ Ind Med 1993;50:586--97.

25. Bakke PS, Baste V, Hanoa R, Gulsvik A. Prevalence of obstructive lung disease in a general population: relation to occupational title and exposure to some airborne agents. Thorax 1991;46:863-70.

26. Axelsson G, Rylander R, Schmidt A. Mortality and incidence of tumours among ferrochromium workers. $\mathrm{Br} \mathrm{J}$ Ind $\mathrm{Med}$ 1980;37:121-7.

27. Moulin JJ, Portefaix P, Wild P, Mur JM, Smagghe G, Mantout B. Mortality study among workers producing ferroalloys and stainless steel in France. Br J Ind Med 1990;47:537-43.

28. Choudat D, Frisch C, Barrat G, Kholti A El, Conso F. Occupational exposure to amorphous silica dust and pulmonary function. Br J Ind Med 1990;47:763-6.

29. Johansen B, Vale JR. Respiratory health in workers exposed to ferrosilicon dust. Eur J Respir Dis 1982;62:86-7.

30. Wilson RK, Stevens PM, Lovejoy HB, Bell ZG, Richie RC. Effects of chronic amorphous silica exposure on sequential pulmonary function. J Occup Med 1979;21:399 — 402.

31. Reuzel PGJ, Bruijntjes JP, Feron VJ, Woutersen RA. Subchronic inhalation toxicity of amorphous silicas and quartz dust in rats. Food Chem Toxicol 1991;29:341-54.

32. Salvan A, Stayner L, Steenland K, Smith R. Selecting an exposure lag period. Epidemiology 1995;6:387-90.

33. Wilkenfeld M. Metal compounds and rare earths. In: Rom WN, editor. Environmental and occupational medicine. Boston/Toronto/London: Little Brown, 1992:815-30.

34. Kjuus H, Andersen A, Langård S, Knudsen KE. Cancer incidence among workers in the Norwegian ferroalloy industry. $\mathrm{Br} \mathrm{J}$ Ind Med 1986;43:227-36.

35. Roels HA, Ghyselen P, Buchet JP, Ceulemans E, Lauwerys RR. Assessment of the permissible exposure level to manganese in workers exposed to manganese dioxide dust. $\mathrm{Br} \mathrm{J}$ Ind Med 1992:49:25-34.

36. Broch C. Silicosis caused by the smoke dust in a ferro-silicon and ferro-chromium smelting-plant [dissertation]. Oslo: Olaf Norlis Forlag, 1953.

Received for publication: 20 January 1997 